\title{
Thrips species associated with varieties of the native Cerrado fruit tree Hancornia speciosa
}

\author{
Jéssica Ferreira Silva ${ }^{1}$, Jaqueline Magalhães Pereira ${ }^{2}$, Charlles Brandão Silva Rocha ${ }^{3}$, \\ André Júnio Andrade Peres ${ }^{4}$, Élison Fabrício Bezerra Lima ${ }^{5}$
}

\begin{abstract}
Studies of insects associated with the fruit tree Hancornia speciosa Gomes (Apocynaceae), a native of the Brazilian Cerrado popularly known as "mangabeira", are generally restricted to reports from seedling nurseries. Thrips predominate among insects that attack this crop. This study investigated the species of Thysanoptera that use this native fruit as a host, and which variety they prefer. The $H$. speciosa varieties speciosa s.str., cuyabensis, gardneri and pubescens were obtained from the collections of the ex-situ germplasm bank of native species at the Escola de Agronomia, Universidade Federal de Goiás, Goiânia, Brazil. Evaluations were conducted from January through December 2016. A total of 1679 individual thrips were identified. Thrips were most abundant on pubescens (79.08\%), followed by gardneri $(15.02 \%)$, cuyabensis $(4.71 \%)$, and speciosa $(1.19 \%)$. Representatives of the family Thripidae predominated in all collections, especially Coremothrips nubiculus and Heliothrips longisensibilis. The foliar trichomes present in var. pubescens may account for the high abundance of thrips on this variety. Heliothrips longisensibilis is recorded in Brazil for the first time.
\end{abstract}

Index terms: Thysanoptera, mangabeira, foliar trichomes, diversity.

\section{Espécies de tripes associadas a variedades da frutífera nativa do Cerrado Hancornia speciosa}

Corresponding author: jessicaferreira.agronoma@gmail. com

Received: March 25, 2019 Accepted: August 12, 2019

Copyright: All the contents of this journal, except where otherwise noted, is licensed under a Creative Commons Attribution License.

\section{(cc) $\mathrm{EY}$}

Resumo - A mangabeira Hancornia speciosa Gomes (Apocynaceae) é uma planta nativa do Cerrado brasileiro, e os estudos de insetos associados a esta espécie vegetal geralmente são restritos a relatos de ocorrência em viveiro. Deste modo, é necessário avaliar quais insetos estão associados a esta espécie. Entre as espécies de insetos que atacam a cultura, destacam-se os tripes. Neste trabalho, estudou-se a diversidade de tripes associados a variedades de $H$. speciosa, visando a conhecer as espécies de Thysanoptera que utilizam essa frutífera nativa como hospedeira. As coletas foram realizadas no banco de germoplasma ex situ de espécies nativas da Escola de Agronomia - Universidade Federal de Goiás, Goiânia, Brasil, contendo as variedades speciosa, cuyabensis, gardneri e pubescens. As avaliações ocorreram no período de janeiro a dezembro de 2016. Um total de 1.679 indivíduos de tripes foram identificados. A maior abundância de tripes foi coletada na variedade pubescens $(79,08 \%)$, seguida por gardneri $(15,02 \%)$, cuyabensis $(4,71 \%)$ e speciosa $(1,19 \%)$. Representantes da família Thripidae foram predominantes em todas as coletas, com destaque para as espécies Coremothrips nubiculus and Heliothrips longisensibilis. Possivelmente, a presença de tricomas foliares presentes na variedade pubescens é um fator que contribui para a maior abundância nesta variedade. Heliothrips longisensibilis é registrada pela primeira vez no Brasil.

Termos para indexação: Thysanoptera, mangabeira, tricomas foliares, diversidade.

\footnotetext{
${ }^{1} \mathrm{PhD}$ student in Agronomy, School of Agronomy, Federal University of Goiás, Goiânia-GO, Brazil. E-mail: jessicaferreira.agronoma@gmail. com ${ }^{\text {(ORCID } 0000-0001-8984-5621)}$

2Professor, School of Agronomy, Federal University of Goiás, Goiânia-GO, Brazil. E-mail: jmpereira@ufg.br (ORCID 0000-0002-4911-555X) ${ }^{3}$ Forest Engineer, School of Agronomy, Federal University of Goiás, Goiânia-GO, Brazil. E-mail: charlles.brandaosr@gmail.com ${ }^{\text {(ORCID 0000- }}$ $0001-9635-998 \times)$

${ }^{4} \mathrm{PhD}$ student in Agronomy, School of Agronomy, Universidade Federal de Goiás. Goiânia-GO, Brasil. E-mail: andrejaperes@yahoo.com ${ }^{(0 \mathrm{Rc} I \mathrm{D}}$ 0000-0002-7964-0611)

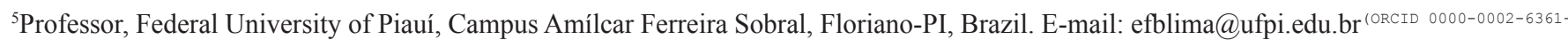
0928)
} 


\section{Introduction}

Hancornia speciosa Gomes (Apocynaceae), popularly known as "mangabeira", is native to the Brazilian Cerrado and also found in the northeastern and northern regions of Brazil (LORENZI, 1992). The flavorful and nutritious fruits of $H$. speciosa are mainly consumed in natura and are also used in ice cream (LEDERMAN et al., 2000), with a good level of acceptance and a low fat content (SANTOS \& SILVA, 2012). The fruit is generally harvested in an extractive manner (VIEIRA NETO, 2001). Studies of $H$. speciosa are recent, compared with other cultivated fruits (GANGA et al., 2010).

The mangaba fruit is well suited for consumption in natura and processing, as it has an ideal $\mathrm{pH}$, titratable acidity, sugar reducers, soluble solids, and high fiber content (ASSUMPÇÃO et al., 2014). The fruit also has high antioxidant activity and high levels of ascorbic, phenolic and chlorogenic acids and rutin. The fruit also has antimutagenic and anticancer potential (LIMA et al., 2015), and may potentially increase the uptake of glucose, with an anti-diabetic effect (PEREIRA et al., 2015). A predominant characteristic of this species is the production of latex. ALMEIDA et al. (2014) studied the properties of mangabeira latex and found significant angiogenic activity, with no cytotoxic agents or genotoxic effects. MARINHO et al. (2011) demonstrated that mangabeira latex has anti-inflammatory activity. In addition to the phytotherapeutic effects, $H$. speciosa latex has properties comparable to the natural rubber of Hevea brasiliensis (Willd., formerly Adr. De Juss.) Muell-Arg. (MALMONGE et al., 2009).

Cultivation of $H$. speciosa is still in its early stages. The few studies of the entomofauna (MICHEREFF FILHO; MICHEREFF, 2006) are mostly limited to reports of occurrence, with little information on ecology. Certain varieties of $H$. speciosa have plant structures, such as foliar trichomes, that may favor certain insects.

Few insects are currently known to be associated with $H$. speciosa, and reports of occurrence are mostly from nurseries or young orchards (PEREIRA et al., 2010). Most insects reported occur at low population levels, without causing economic damage (VIEIRA NETO et al., 2002). ALVES-SILVA et al. (2013) evaluated the population of Thysanoptera, commonly termed thrips, on three species of Cerrado plants including $H$. speciosa, and found that Frankliniella musaeperda Hood, was particularly associated with mangabeira flowers. PEREIRA et al. (2010) observed injuries to fruits caused by unidentified species of thrips. These insects have agricultural importance due to the direct and indirect damage they cause, as in cases of virus transmission (MONTEIRO et al., 2001).
Preliminary evaluations in this study found injuries to $H$. speciosa fruits and leaves, which could impair the marketing value of the whole fruit for consumption. This damage was associated with thysanopterans, maing it desirable to identify the main species of thrips associated with this plant. To support future management strategies, it is also important to evaluate varieties of $H$. speciosa that may be alternative hosts for thrips.

For these reasons, knowledge of the richness, abundance, and diversity of thrips on $H$. speciosa varieties is needed. This study investigated the diversity of Thysanoptera associated with four varieties of $H$. speciosa.

\section{Material and Methods}

Hancornia speciosa plants used for the study of thrips were obtained from the ex situ germplasm bank of native species $\left(16^{\circ} 35^{\prime} 39^{\prime}\right.$ ' $\mathrm{S}$ and $49^{\circ} 17^{\prime} 07^{\prime}$ ' W, $733 \mathrm{~m}$ a.s.1.) at the School of Agronomy, Universidade Federal de Goiás, Goiânia, Brazil. Hancornia speciosa seedlings were transplanted in 2005. The plants were installed in four blocks, with four varieties of $H$. speciosa (speciosa s.str., cuyabensis, gardneri and pubescens), with a spacing of $5 \times 6 \mathrm{~m}$. Hancornia speciosa var. speciosa has a leaf with a petiole measuring 9 to $15 \mathrm{~mm}$ long, leaf blade $6 \mathrm{~cm}$ long and $2 \mathrm{~cm}$ wide, and glabrous. Hancornia speciosa var. cuyabensis has a leaf that is glabrous externally, a large corolla, calyx glabrous externally, petiole $3 \mathrm{~mm}$ long, and limbus 4 to $10 \mathrm{~cm}$ long and 1.5 to $3.0 \mathrm{~cm}$ wide. The leaf of $H$. speciosa var. gardneri has a petiole 3 to $5 \mathrm{~mm}$ long, leaf blade 4 to $10 \mathrm{~cm}$ long and 1.5 to $3.0 \mathrm{~cm}$ wide, and is glabrous on the dorsal surface or pubescent on the central vein. Hancornia speciosa var. pubescens differs from the other varieties in the number of trichomes on each leaf and in the densely pubescent branches; the petiole is 3 to $5 \mathrm{~mm}$ long, with the leaf blade measuring 7 to 10 $\mathrm{cm}$ long and $4 \mathrm{~cm}$ wide, and is glabrous on the adaxial face or the lower part of the pubescent central vein (MONACHINO, 1945, cited by SILVA JUNIOR \& LÉDO, 2006).

Two plants of each variety were randomly selected per block. Two branches were collected from the upper middle third of each plant; six leaves per branch were evaluated, totaling 96 leaves per variety per collection. The collected branches were packed in plastic bags, labeled, and transported to the laboratory. In the laboratory, these materials were kept refrigerated at $10{ }^{\circ} \mathrm{C}$, for a maximum of three days.

The thrips were collected from the leaves with soft bristle brushes under a stereomicroscope. After evaluation, the leaf area was measured using a leaf-area meter (Model CI-202 portable laser). The evaluations 
took place on average every 15 days, in the morning, from January through December 2016. The captured thrips were transferred with a brush to an Eppendorf@ tube $(1.5 \mathrm{~mL})$ containing $70 \%$ ethanol. Then, the insects were mounted on permanent microscopy slides and identified following MOUND and MARULLO (1996) and MONTEIRO and MOUND (2012). To measure leaf trichomes, three areas of $1 \mathrm{~cm}^{2}$ (central groove on the lower, middle and upper leaf) of the varieties pubescens and gardneri, and trichomes were counted using a stereomicroscope.

To evaluate differences in the abundances of thrips species on the four $H$. speciosa varieties, faunistic analyses were performed to classify constancy, abundance, and frequency. Constancy was calculated by the formula of BODENHEIMER (1938): $\mathrm{C}=(\mathrm{P} \times 100)$ / $\mathrm{N}$ where: $\mathrm{P}=$ number of collections with the species present and $\mathrm{N}=$ total number of collections. According to the percentages obtained, the species of thrips were separated into three categories: constant species (W), present in more than $50 \%$ of the collections; accessory species (Y), present in $25 \%$ to $50 \%$ of the collections; and accidental species $(Z)$, present in less than $25 \%$ of the collections.

Abundance was calculated by standard deviation, standard error of the mean and confidence interval (CI). According to DAJOZ (1983), abundance was classified as: $(\mathrm{R})$ rare, number of individuals below the lower limit of the CI at 1\% probability; (D) dispersed, number of individuals between the lower limits of the $\mathrm{CI}$ at $5 \%$ and $1 \%$; (C) common, number of subjects within the $5 \% \mathrm{CI}$; (A) abundant, number of subjects between the upper limits of the $\mathrm{CI}$ at $5 \%$ and $1 \%$; and (VA) very abundant, number of subjects above the upper limit of $1 \% \mathrm{CI}$.

Frequency was calculated using the formula of SILVEIRA NETO et al. (1976): $\mathrm{F}=\mathrm{n} / \mathrm{N}$ x100, where $\mathrm{F}=$ frequency $(\%), \mathrm{n}=$ number of individuals of each species collected, and $\mathrm{N}=$ total number of individuals of all species collected. Based on the confidence interval of the mean frequencies with $5 \%$ probability, the species were divided into: $\mathrm{VF}=$ very frequent; $\mathrm{F}=$ frequent; or $\mathrm{NF}=$ not frequent.

The data for C. nubiculus and H.longisensibilis were compared by Generalized Linear Models (GLM) with the Quasi-Poisson distribution. To separate the means, the Friedman test was used, with the package 'drc' (RITZ; STREIBIG, 2008) in the R statistical freeware (R CORE TEAM, 2016).

\section{Results and Discussion}

The total of 1679 thrips collected included 19 species belonging to three families, Aeolothripidae, Phlaeothripidae, and Thripidae (Table 1). Most of the thrips are known to be phytophagous $(99.28 \%)$ and a few are predaceous $(0.71 \%)$. Franklinothrips vespiformis (Crawford; Aeolothripidae) is predaceous. The six species of the family Phlaeothripidae were found in low numbers (Table 1). Species of Thripidae predominated; Coremothrips nubiculus Hood and Heliothrips longisensibilis Xie, Mound and Zhang were the most abundant, comprising $93.81 \%$ of the individuals collected.

This study is the first to report all the species of thrips that were found on $H$. speciosa in a particular area. The predominance of phytophagous species, mainly C. nubiculus.

The species $F$. vespiformis, C. nubiculus, Haplothrips gowdeyi (Franklin), H. longisensibilis, and Leucothrips theobromae (Priesner) and the genera Pseudophilothrips, Karnyothrips, Chaetanaphothrips, Rhamphothrips, Mirothrips, and Scolothrips have not been reported previously in Goiás state. Coremothrips nubiculus was previously reported from the state of Santa Catarina (LIMA, 2019). The genus Leucothrips was listed previously in the state of Santa Catarina (LIMA, 2019). This study provides the first record of L. theobromae in Brazil. Similarly, Trybomia sp. has been recorded in three states of the southeast region and one state in the south. In Brazil, only three species belonging to this genus have been: T. gossypii (Hood), T. intermedia (Bagnall), and T. mendesi Moulton (LIMA, 2019). Only S. sexmaculatus has been cataloged, in the states of Bahia and São Paulo (LIMA, 2019). Only one species of Rhamphothrips, $R$. pandens Sakimura, was previously recorded in the state of São Paulo (LIMA, 2019). The genus Pseudophilothrips has recorded in the states of Amazonas, Espírito Santo, Minas Gerais, São Paulo, Rio de Janeiro and Paraná (LIMA, 2019). Karnyothrips has been recorded in the states of Pará, Minas Gerais, São Paulo and Rio de Janeiro (LIMA, 2019).

Franklinothrips vespiformis is a predator of mites and other small insects (MOUND; REYNAUD, 2005). Trybomia sp. and Mirothrips sp. were found in low numbers. Some reports have considered Trybomia species, such as $T$. intermedia and T. mendesi, as predators (LEITE et al., 2012); however, this requires further investigation. Species of Mirothrips are presumably predators, as members of this genus feed on wasp eggs (CAVALLERI et al., 2013). 
Four individuals of Frankliniella, one adult and three immatures, were collected. From Goiás state, only 11 species of Thysanoptera have been cataloged (LIMA, 2019), including four belonging to the genus Frankliniella, i.e., F graminis Cavalleri and Mound, $F$. zucchini Nakahara \& Monteiro, F. schultzei Trybom, and $F$. condei John (LIMA, 2019). This genus contains species that transmit viruses, specifically Tospoviruses, and thus are considered key pests of agricultural importance (GHOSH et al., 2017). The small number of Frankliniella individuals collected may result from the preference of species of this genus for flowers (ALVES-SILVA et al., 2013), a plant organ not analyzed in this study.

Retithrips syriacus (Mayet) occurs in all regions of Brazil (LIMA, 2019). This thrips was found in low numbers and may have been wind-dispersed, because no immature specimens were found to verify their development on $H$. speciosa. In Brazil, $R$. syriacus is also found on eucalyptus (MONTEIRO, 2002), Mimosa caesalpiniifolia (HAJI et al., 2009), and Jatropha curcas (SILVA et al., 2008).

The varieties of $H$. speciosa differed in the number of thrips. The pubescens variety bore $79.08 \%$ of the thrips identified. The variety with the second-highest abundance of thrips was gardneri, with $15.02 \%$ of the individuals collected. The cuyabensis and speciosa varieties had low proportions of $4.71 \%$ and $1.19 \%$, respectively.

On the pubescens variety the most abundant species was $C$. nubiculus, comprising $95.65 \%$ of the individuals, including both immatures and adults. On the gardneri variety, $H$. longisensibilis comprised $54.92 \%$ of individuals. On pubescens and cuyabensis, the percentage of occurrence was almost the same as $H$. longisensibilis. Of all the varieties, speciosa had the fewest individuals collected for all species; during the study period, only 21 specimens were found on speciosa.

Heliothrips is likely to be native to South America (MOUND; MONTEIRO 1997), but one species, $H$. haemorrhoidalis, is widespread. A species recently described from China, however, put that assumption in doubt. Heliothrips longisensibilis was described with material collected in China (XIE et al., 2019), but is here recorded for the first time in Brazil. A possibility is that the species might have been transported through commodity trade from central Brazil, but only further studies on population genetics will help clarifying the issue.

The gardneri variety had the largest population of $H$. longisensibilis. . This variety has glabrous leaves on the adaxial side or pubescence on the midvein of the abaxial side. However, SCOTT-BROWN and SIMMONDS (2006) reported a population of $H$. haemorrhoidalis on plants with coriaceous or smooth leaves. In $H$. speciosa, this thrips caused injuries consisting of whitish scores, usually over large areas, starting from the edges of the leaves towards the center and usually combined with dark excrement. This type of injury resembles attacks of mites from the family Tetranychidae, although thrips do not produce the associated web (LIMA et al., 2012). This species was reported by LIMA et al. (2016) as causing chlorotic spots on leaves of Plumeria sp. (Apocynaceae).

The abundance and richness of predatory thrips was similar for all varieties, due to the predominance of phytophagous species. Varieties cuyabensis and speciosa did not have any specimens of $F$. vespiformis or Scolothrips sp., predaceous species collected in this study.

The phytophagous thrips C. nubiculus (Figure 1) was abundant on var. pubescens. The pubescens variety also had the highest numbers of thrips, indicating that the pilosity ( 3413 trichomes $\mathrm{cm}^{-2}$ ) on the abaxial side of the leaf may favor this insect. However, $H$. longisensibilis (Figure 2) stood out in var. gardneri in relation to the other varieties. The gardneri variety has sparse hairs on the central groove of the leaf (115 trichomes $\mathrm{cm}^{-2}$ ), and thus may also attract specific thrips species. The glabrous-leaved varieties cuyabensis and speciosa had low numbers of thrips.

Comparison of the leaf structures of the different varieties with the number of thrips found on each variety suggests that var. pubescens is a primary host and the others are secondary hosts. MILNE and WALTER (2000) noted that thrips alternate between hosts forsurvival, but not to reproduce. Thus, these insects accumulate on secondary hosts, but in lower numbers than on the primary hosts. In addition, thrips only reach large numbers on primary hosts. Without the presence of these primary hosts, few individuals survive on secondary hosts.

The abundance and diversity of thrips correlates with the structural characteristics of the environment (PINENT et al., 2008), considering important habitat requirements, among them space availability, protection from predators, foraging efficiency, and reproduction (CARVALHO et al., 2006). MOUND and MARULLO (1996) defined plants that possess these characteristics as host plants of thrips. Thrips search for favorable microhabitats, migrating from host to host during the year (MOUND; MARULLO, 1996), because plant phenology changes throughout the year due to seasonal variations (GILL et al., 1998).

The leaf trichomes on $H$. speciosa can provide a microhabitat for the thrips. The presence of specific structures, such as pilosity and domatia may determine the abundance of these insects (PINENT et al., 2005; CAVALLERI et al., 2006). This study showed which 
varieties with trichomes showed higher abundances of thysanopteran species.

The faunistic analysis (Table 2) indicated two species as constant and one as accessory. Several species were found in small numbers, in some cases only a single individual, and therefore $83.33 \%$ of the species were classified as accidental. With regard to abundance, most species were classified as either rare or common. No dispersed species were found. Only $H$. longisensibilis was abundant.

Coremothrips nubiculus was classified as very abundant, being found in all evaluations. With regard to frequency, species with large numbers were classified as very frequent (Table 2). With regard to constancy, abundance, and frequency, most species occurred in low numbers except for $C$. nubiculus and H. longisensibilis. According to SILVEIRA NETO et al. (1976), diversity index values are low at sites where interspecific competition occurs. Thrips are easily carried by the wind (MOUND; MARULLO, 1996), and species found in small numbers may have been wind-dispersed and do not naturally develop on a particular plant species. However, the presence of immatures indicated that these species are completing their life cycles on $H$. speciosa.
Coremothrips nubiculus and Heliothrips longisensibilis were most commonly foundin the study. Coremothrips nubiculus was seen during most of the year, particularly in January, March, September, and December. The population peaked in December, with 368 specimens found. At that time of year, the population of thrips increased and then declined rapidly.

Studies on thrips are highly useful because these insects cause direct and indirect damage to many plant species. Some thrips species found in this study are virus vectors, which makes it desirable to investigate if these plants can be hosts of viruses.

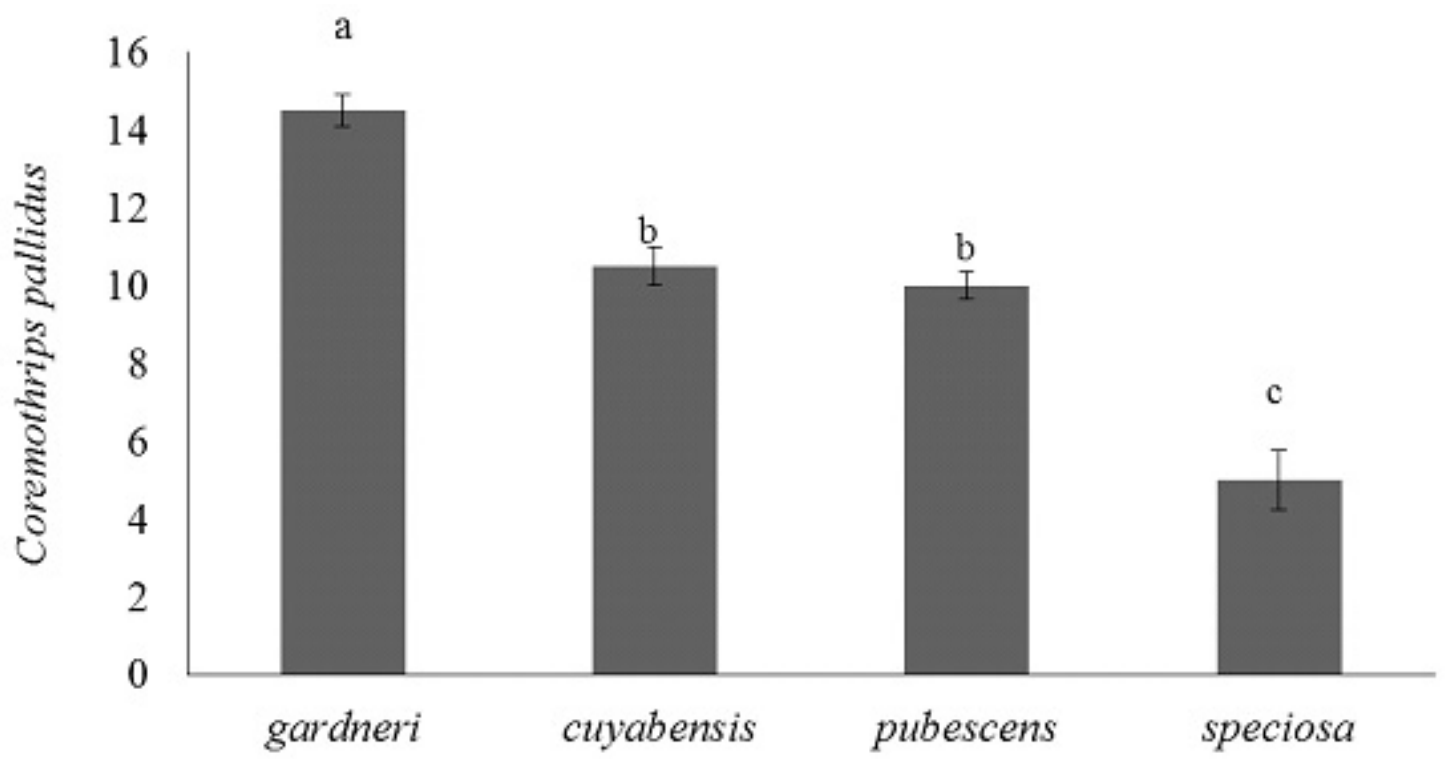

Figure 1. Mean abundance (whiskers indicate \pm SE) of Coremothrips nubiculus on different varieties of Hancornia speciosa Gomes (Apocynaceae). Differences among means indicated by different letters, evaluated by Friedman test. 


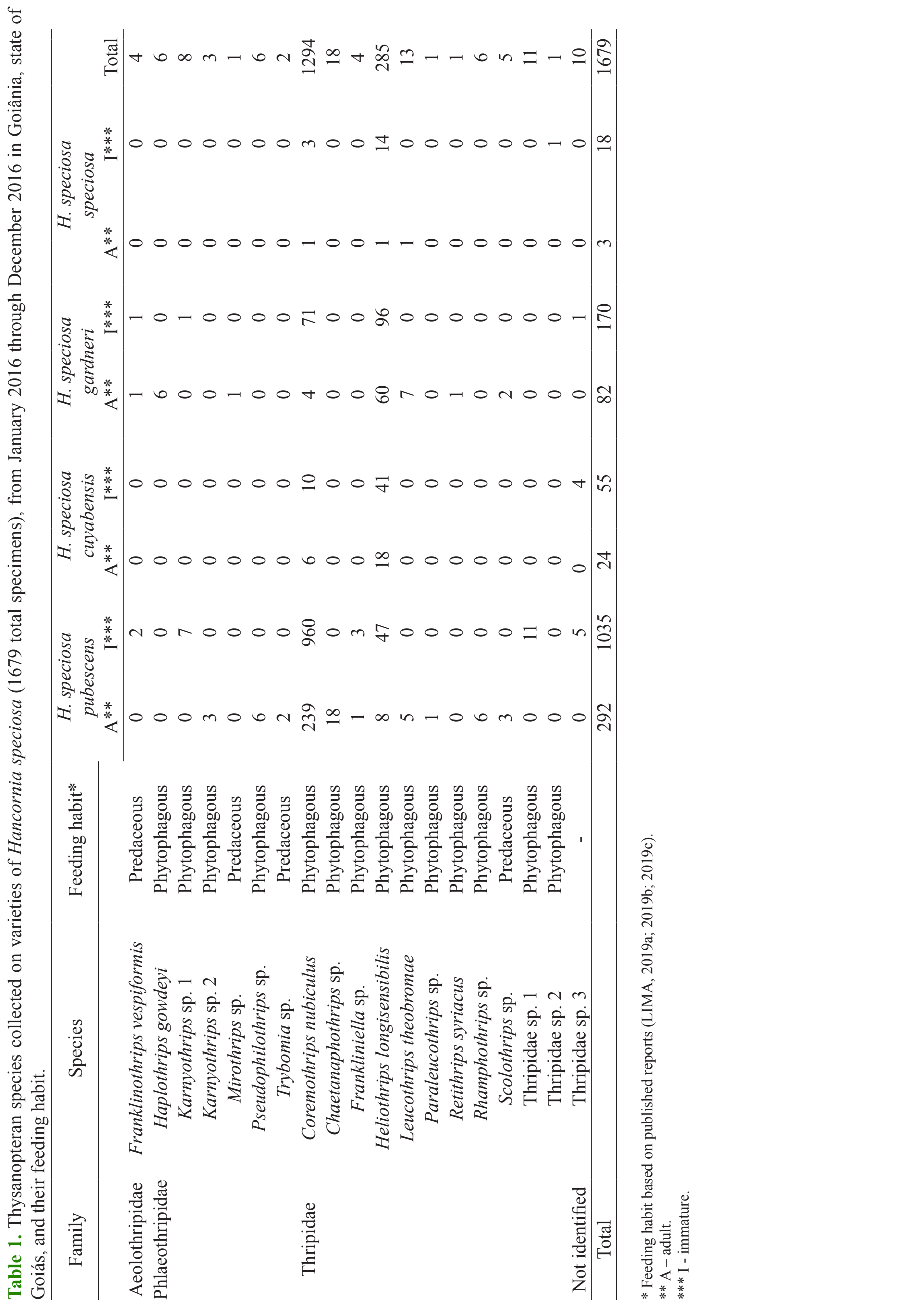

Rev. Bras. Frutic., Jaboticabal, 2019, v. 41, n. 5: (e-053) 
Table 2. Constancy, abundance, and frequency* of thysanopteran species collected on Hancornia speciosa from January 2016 through December 2016 in Goiânia, state of Goiás.

\begin{tabular}{|c|c|c|c|c|}
\hline Family & Species & Constancy $^{1}$ & Abundancy $^{2}$ & Frequency $^{3}$ \\
\hline Aeolothripidae & Franklinothrips vespiformis & $\mathrm{Z}$ & $\mathrm{R}$ & $\mathrm{F}$ \\
\hline \multirow[t]{6}{*}{ Phlaeothripidae } & Haplothrips gowdeyi & Z & $\mathrm{C}$ & $\mathrm{F}$ \\
\hline & Karnyothrips sp. 1 & Z & $\mathrm{C}$ & $\mathrm{F}$ \\
\hline & Karnyothrips sp. 2 & $\mathrm{Z}$ & $\mathrm{R}$ & NF \\
\hline & Mirothrips sp. & $\mathrm{Z}$ & $\mathrm{R}$ & NF \\
\hline & Pseudophilothrips sp. & $\mathrm{Z}$ & $\mathrm{C}$ & $\mathrm{F}$ \\
\hline & Trybomia sp. & $\mathrm{Z}$ & $\mathrm{R}$ & NF \\
\hline \multirow[t]{11}{*}{ Thripidae } & Coremothrips nubiculus & $\mathrm{W}$ & VA & VF \\
\hline & Chaetanaphothrips sp. & Y & $\mathrm{C}$ & VF \\
\hline & Frankliniella sp. & Z & $\mathrm{R}$ & $\mathrm{PF}$ \\
\hline & Heliothrips longisensibilis & $\mathrm{W}$ & A & VF \\
\hline & Leucothrips theobromae & Z & $\mathrm{C}$ & NF \\
\hline & Paraleucothrips sp. & Z & $\mathrm{R}$ & NF \\
\hline & Retithrips syriacus & Z & $\mathrm{R}$ & NF \\
\hline & Rhamphothrips sp. & $\mathrm{Z}$ & $\mathrm{C}$ & $\mathrm{F}$ \\
\hline & Scolothrips sp. & Z & $\mathrm{C}$ & $\mathrm{F}$ \\
\hline & Thripidae sp. 1 & Z & $\mathrm{C}$ & $\mathrm{F}$ \\
\hline & Thripidae sp. 2 & Z & $\mathrm{R}$ & NF \\
\hline
\end{tabular}

*Terms based on BODENHEIMER (1938); DAJOZ (1983); SILVEIRA NETO et al. (1976).

${ }^{1} \mathrm{~W}=$ Constant, $\mathrm{Y}=$ Acessory, and $\mathrm{Z}=$ Accidental.

${ }^{2} \mathrm{VA}=$ Very abundant, $\mathrm{A}=$ Abundant, $\mathrm{C}=\mathrm{Common}, \mathrm{D}=$ Dispersed, and $\mathrm{R}=$ Rare.

${ }^{3} \mathrm{VF}=$ Very Frequent, $\mathrm{F}=$ Frequent, and $\mathrm{NF}=$ not frequent.

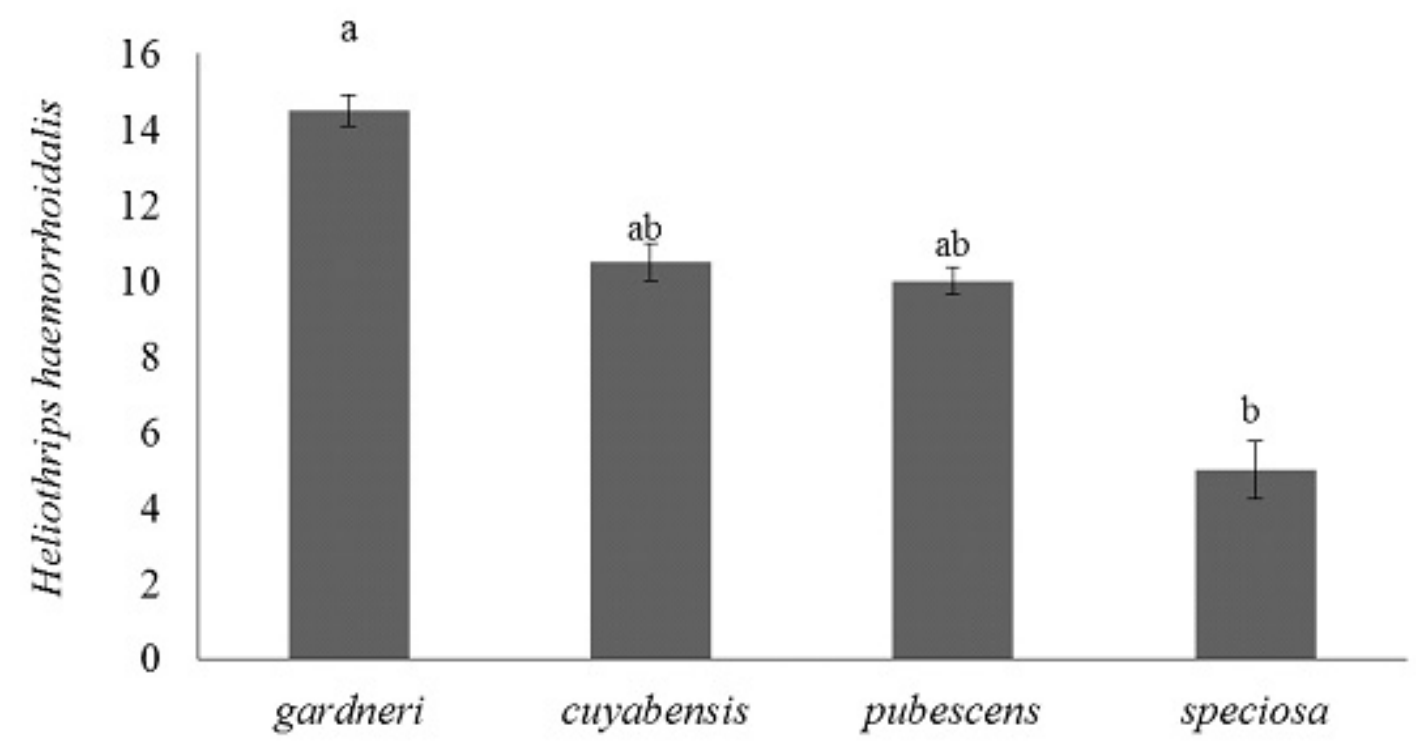

Figure 2. Mean abundance (whiskers indicate \pm SE) of Heliothrips longisensibilis on different varieties of Hancornia speciosa Gomes (Apocynaceae). Differences among means indicated by different letters. evaluated by Friedman test. 


\section{Conclusions}

The varieties of Hancornia speciosa differed as to the abundance of thrips species. The thrips species found belong mainly to the families Thripidae and Phlaeothripidae. Several species are reported for the first time in association with $H$. speciosa (e.g., Coremothrips nubiculus and Heliothrips longisensibilis).

\section{Acknowledgments}

We thank the National Council of Scientific and Technological Development (CNPq) for the scholarship granted to the first author, as well as the Fundação de Amparo à Pesquisa do Estado de Goiás (201200765800779, No. 007/2012 - PRONEX - FAPEG) for the financial assistance granted for this research project.

\section{References}

ALMEIDA, L.M.; FLORIANO, J.F.; RIBEIRO, T.P.; MAGNO, L.N.; MOTA, L.S.L.S.; PEIXOTO, N.; MRUÉ, F.; MELO-REIS, P.; LINO JUNIOR, R.S.; GRAEFF, C.F.O.; GONÇALVES, P.J. Hancornia speciosa latex for biomedical applications: physical and chemical properties, biocompatibility assessment and angiogenic activity. Journal of Materials Science: Materials in Medicine, Dordrecht, v.25, n.9, p.2153-2162, 2014.

ALVES-SILVA, E.; MARUYAMA, P.K.; CAVALLERI, A.; DEL-CLARO, K. Flower stage and host plant preference by floral herbivore thrips (Insecta: Thysanoptera: Frankliniella) in a Brazilian savanna. Studies on Neotropical Fauna and Environment, Abingdon, v.48, p.25-31, 2013.

ASSUMPÇÃO, C.F.; BACHIEGA, P.; MORZELLE, M.C.; NELSON, D.L.; NDIAYE, E. A.; OLIVEIRA RIOS, A.; SOUZA, E.C. Characterization, antioxidant potential and cytotoxic study of mangaba fruits. Ciência Rural, Santa Maria, v.44, n.7, p.1297-1303, 2014.

BODENHEIMER, F.S. Problems of animal ecology. Oxford: Oxford University Press, 1938.

CARVALHO, L.M.; BUENO, V.H.P.; MENDES, S.M. Ocorrência e flutuação populacional de tripes, pulgões e inimigos naturais em crisântemo de corte em casa de vegetação. Bragantia, Campinas, v.65, p.139-146, 2006
CAVALLERI, A.; ROMANOWSKI, H.P.; REDAELLI L, R. Thrips species (Insecta, Thysanoptera) inhabiting plants of the Parque Estadual de Itapuã, Viamão, Rio Grande do Sul state, Brazil. Revista Brasileira de Zoologia, Curitiba, v. 23, p.367-374, 2006.

CAVAlLERI, A.; SOUZA, A.R.; PREZOTO, F.; MOUND, L.A. Egg predation within the nests of social wasps: a new genus and species of Phlaeothripidae, and evolutionary consequences of Thysanoptera invasive behaviour. Biological Journal of the Linnean Society, London, v.109, n.2, p.332-341, 2013.

DAJOZ, R. Ecologia geral. 4.ed. Petrópolis: Vozes, 1983.

GANGA, R.M.D.; FERREIRA, G.A.; CHAVES, L.J.; NAVES, R.V.; NASCIMENTO, J.D. Caracterização de frutos e árvores de populações naturais de Hancornia speciosa Gomes do Cerrado. Revista Brasileira de Fruticultura, Jaboticabal, v.32, n.1, p.101-113, 2010.

GHOSH, A.; DEY, D.; TIMMANNA; BASAVARAJ, Y.B.; MANDAL, B.; JAIN, R.K. Thrips as the vectors of Tospoviruses in indian agriculture. In: MANDAL, B.; RAO, G.; BARANWAL, V.; JAIN, R. (ed.). A century of plant virology in India. Singapore: Springer, 2017. p.537-561.

GILL, D.S.; AMTHOR, J.S.; BORMANN, F.H. Leaf phenology, photosynthesis, and persitence of sampling and shrubs in a mature northern hardwood forest. Tree Physiology, Oxford, v.18, p.281-289, 1998.

HAJI, F.N.P.; OLIVEIRA, J.E.M.; ALENCAR, J.A.; GERVÁSIO, R.C.R. G.; SANTOS, V.F.C.; MOREIRA, N.A. Pragas e alternativas de controle. In: SOARES, J.M.; LEÃO, P.C.S. (ed.). A vitivinicultura no Semiárido brasileiro Brasília. Petrolina: Embrapa Semi-Árido, 2009. p.515-539.

LEDERMAN, I.E.; SILVA JÚNIOR, J.F.; BEZERRA, J.E.F.; ESPÍNDOLA, A.C.M. Mangaba (Hancornia speciosa Gomes). Jaboticabal: Funep, 2000. 35p.

LEITE, G.L.D.; VELOSO, R.V.D.S.; ZANUNCIO, J.C.; FERNANDES, G.W.; ALMEIDA, C.I.M.; FERREIRA, P.S.F.; ALONSO, J.; SERRÃO, J.E. Seasonal abundance of hemipterans on Caryocar brasiliense (Malpighiales: Caryocaraceae) trees in the Cerrado. Florida Entomologist, Washington, v.95, n.4, p.862-872, 2012. 
LIMA, E.F.B. Phlaeothripidae: catálogo taxonômico da fauna do Brasil. Rio de Janeiro: Jardim Botânico, 2019c. Disponível em: http://fauna.jbrj.gov.br/fauna/ faunadobrasil/15523/>. Acesso em: 10 jan. 2019.

LIMA, E.F.B. Thripidae: catálogo taxonômico da fauna do Brasil. Rio de Janeiro: Jardim Botânico, 2019b. Disponível em: http://fauna.jbrj.gov.br/fauna/ faunadobrasil/9510/. Acesso em: 10 jan. 2019.

LIMA, E.F.B. Thysanoptera: catálogo taxonômico da fauna do Brasil. Rio de Janeiro: Jardim Botânico, 2019a. Disponível em: http://fauna.jbrj.gov.br/fauna/ faunadobrasil/316/. Acesso em: 10 jan. 2019.

LIMA, E.F.B.; LOPES, E.M.; BERTIFILHO, E. Heliothrips haemorrhoidalis (Bouché, 1833) (Thysanoptera: Thripidae) danificando samambaia-de-metro (Polypodium persicifolium Desv.) (Polypodiales: Polypodiaceae) no Brasil. Brazilian Journal of Agriculture, Piracicaba, v.87, n.2, p.119-121, 2012.

LIMA, E.F.B.; THOMAZINI, M.; SANTOS, R.S.; LOPES, E.M.; SAITO, L.; ZUCCHI, R.A. New findings of thrips (Thysanoptera: Thripidae) on plants in Brazil. Florida Entomologist, Washington, v.99, n.1, p.146-149, 2016.

LIMA, J.P.; AZEVEDO, L.; DE SOUZA, N.J.; NUNES, E.E.; BOAS, E.V.D.B.V. First evaluation of the antimutagenic effect of mangaba fruit in vivo and its phenolic profile identification. Food Research International, New York, v.75, p.216-224, 2015.

LORENZI, H. Árvores brasileiras: manual de identificação e cultivo de plantas arbóreas nativas do Brasil. Nova Odessa: Plantarum. 1992. 28 p.

MALMONGE, J.A.; CAMILLO, E.C.; MORENO, R.M.B.; MATTOSO, L.H.C.; MCMAHAN, C.M. Comparative study on the technological properties of latex and natural rubber from Hancornia speciosa Gomes and Hevea brasiliensis. Journal of Applied Polymer Science, New York, v.111, n.6, p.2986-2991, 2009.

MARINHO, D.G.; ALVIANO, D.S.; MATHEUS, M.E.; ALVIANO, C.S.; FERNANDES, P.D. The latex obtained from Hancornia speciosa Gomes possesses antiinflammatory activity. Journal of Ethnopharmacology, New York, v.135, n.2, p.530-537, 2011.

MICHEREFF FILHO, M.; MICHEREFF, M.F.F. Pragas. In: SILVA JUNIOR, J.F.S.; LÉDO, A.S. (ed.). A cultura da mangaba. Aracaju: Embrapa Tabuleiros Costeiros, 2006. p. 191-206.
MILNE, M.; WALTER, G.H. Feeding and breeding across host plants within a locality by the widespread thrips Frankliniella schultzei, and the invasive potencial of polyphagous herbivores. Diversity and Distributions, Oxford, v.6, p.243-257, 2000.

MONTEIRO, R.C. The Thysanoptera fauna of Brazil. In: INTERNATIONAL SYMPOSIUM ON THYSANOPTERA, 7., Canberra, 2002. Proceedings [...] Canberra: Australian National Insect Collection, 2002. p.325-340.

MONTEIRO, R.C.; MOUND, L.A. Thysanoptera, In: RAFAEL, J.A.; MELO, G.A.R.; CARVALHO, C.J.B.; CASARI, S.A.; COSTANTINO, R. (ed.). Insetos do Brasil: diversidade e taxonomia. Ribeirão Preto: Holos Editora, 2012. p.407-422.

MONTEIRO, R.C.; MOUND, L.A.; ZUCCHI, R.A. Espécies de Frankliniella (Thysanoptera: Thripidae) de importância agrícola no Brasil. Neotropical Entomology, Londrina, v.30, n.1, p.65-72, 2001.

MOUND, L.A.; KIBBY, G. Thysanoptera: an identification guide. New York: CAB International, 1998. 70p.

MOUND, L.A.; MARULLO, R. The thrips of Central and South America: an introduction (Insecta: Thysanoptera). Gainesville: Associated Publishers, 1996. 487p.

MOUND, L.A.; MONTEIRO, R.C. A review of the genus Heliothrips (Thysanoptera; Thripidae), with a new sisterspecies of the Greenhouse Thrips from south eastern Brazil. Journal of the New York Entomological Society, v.105, p.154-160, 1997.

MOUND, L.A.; REYNAUD, P. Franklinothrips; a pantropical Thysanoptera genus of ant-mimicking obligate predators (Aeolothripidae). Zootaxa, Auckland, v.864, n.1, p.1-16, 2005.

PEREIRA, A.C.; PEREIRA, A.B.D.; MOREIRA, C.C.; BOTION, L.M.; LEMOS, V.S.; BRAGA, F.C.; CORTES, S.F. Hancornia speciosa Gomes (Apocynaceae) as a potential anti-diabetic drug. Journal of Ethnopharmacology, New York, v.161, p.30-35, 2015.

PEREIRA, A.V.; PEREIRA, E.B.C.; SILVA JÚNIOR, J.F.; SILVA, D.B. Mangaba. In: VIEIRA, R.F.; AGOSTINICOSTA, T.; SILVA, D.B.; FERREIRA, F.R.; SANO, S.M. (ed.). Frutas nativas da região Centro-Oeste do Brasil. Brasília: Embrapa Recursos Genéticos e Biotecnologia, 2010. p.221-246. 
PINENT, S.M.J.; MASCARO, F.; BOTTON, M.; REDAELLI, L.R. Thrips (Thysanoptera: Thripidae, Phlaeothripidae) damaging peach in Paranapanema, São Paulo State, Brazil. Neotropical Entomology, Londrina, v.37, n.4, p.486-488, 2008.

PINENT, S.M.J.; ROMANOWSKI, H.P.; REDAELLI, L.R.; CAVALLERI, A. Thysanoptera: plantas visitadas e hospedeiras no Parque Estadual de Itapuã, Viamão, RS, Brasil. Iheringia, Série Zoologia, Porto Alegre, v.95, p.9-16, 2005.

R CORE TEAM. R: A language and environment for statistical computing. Vienna: R Foundation for Statistical Computing, 2016. Disponível em: http://wwwr-projectorg. Acesso em: 10 jan. 2019.

RITZ, C.; STREIBIG, J.C. Nonlinear regression with R. New York: Springer, 2008.

SANTOS, G.G.; SILVA, M.R. Mangaba (Hancornia speciosa Gomes) ice cream prepared with fat replacers and sugar substitutes. Food Science and Technology, Campinas, v.32, n.3, p.621-628, 2012.
SCOTT-BROWN, A.S.; SIMMONDS, M.S.J. Leaf morphology of hosts and nonhosts of the thrips Heliothirps haemorrhoidalis (Bouché). Botanical Journal of the Linnean Society, London, v.152, p.109-130, 2006.

SILVA JUNIOR, J.F.S.; LÉDO, A.S. Botânica. In: SILVA JÚNIOR, J.F.S.; LÉDO, A. S. A cultura da mangaba. Aracaju: Embrapa Tabuleiros Costeiros, 2006. p.25-43.

SILVA, P.H.S.; CASTRO, M.J.P.; ARAÚJO, E.C.A. Tripes (Insecta: Tripidae) associados ao pinhão-manso no Estado do Piauí, Brasil. Revista Brasileira de Oleaginosas e Fibrosas, Campina Grande, v.12, p.125-127, 2008.

SILVEIRA NETO, S.; NAKANO, O.; BARBIN, D.; VILA NOVA, N.A. Manual de ecologia dos insetos. São Paulo: Agronômica Ceres, 1976. 420p.

VIEIRA NETO, R.D. Frutíferas potenciais para os tabuleiros costeiros e baixadas litorâneas. Aracaju: Embrapa Tabuleiros Costeiros, 2002. 216p.

VIEIRA NETO, R.D. Recomendações técnicas para o cultivo da mangabeira. Aracaju: Embrapa Tabuleiros Costeiros, 2001. 20p. (Circular Técnica, 20). 


\section{Erratum of article:}

Silva, Jéssica Ferreira, Pereira, Jaqueline Magalhães, Rocha, Charlles Brandão Silva, Peres, André Júnio Andrade, \& Lima, Élison Fabrício Bezerra. (2019). Thrips species associated with varieties of the native cerrado fruit tree Hancornia speciosa. Revista Brasileira de Fruticultura, 41(5), e-053 2019 https://dx.doi.org/10.1590/0100-29452019053

\section{In the page 5, figure 1:}

where it reads: Coremothrips pallidus

should read: Coremothrips nubiculus

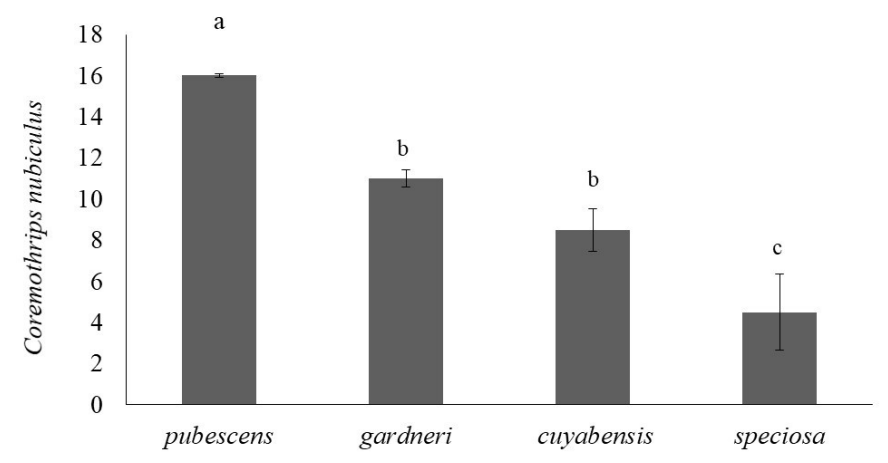

In the page 7 , figure 2 :

where it reads: Heliothrips haemorrhoidalis

should read:

Heliothrips longisensibilis

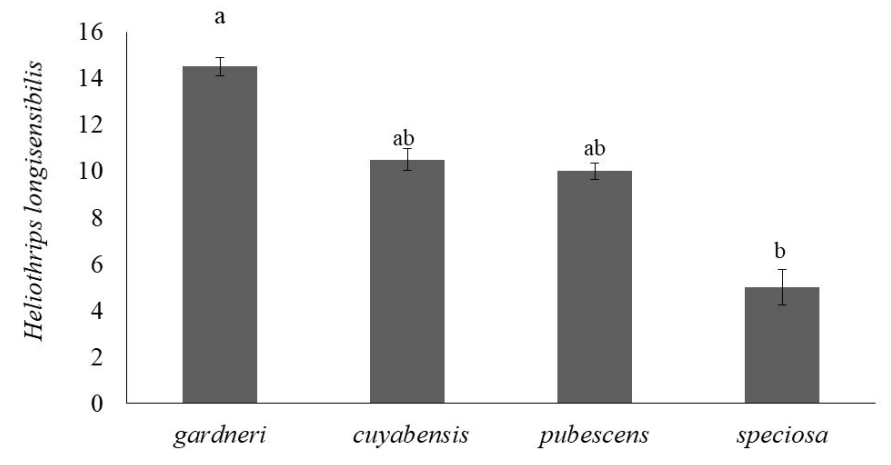

